\title{
REGULARARTICLE \\ STUDIES ON BIOCHEMICAL EFFECTS OF AQUEOUS EXTRACT OF CARICA PAPAYA LEAF ON ALLOXAN-INDUCED DIABETIC ALBINO RATS \\ EZEKWE AHAMEFULA ${ }^{1 *}$, NWADIKE CONSTANCE ${ }^{2}$, EBOAGWU IJEOMA 3 , ODIKA PRINCE4, NJOKU SAMUEL4
}

\author{
${ }^{1}$ Department of Medical Biochemistry, Imo State University, Owerri, Nigeria \\ ${ }^{2}$ Department of Medical Laboratory Science, Imo State University, Owerri, Nigeria \\ 3Department of Food Technology, Federal Institute of Industrial Research Oshodi, Nigeria \\ 4Department of Biochemistry, Michael Okpara University of Agriculture, Umudike, Nigeria
}

\begin{abstract}
Studies on biochemical effects of aqueous extract of Carica papaya leaf on alloxan-induced diabetic albino rats were undertaken. One hundred albino rats of Wistar strain were obtained and divided into five groups of twenty rats each and properly treated with the aqueous extract after four out of the five groups were induced with diabetes. The diabetic induced groups were diabetic control, test groups I (treated with $200 \mathrm{mg} / \mathrm{kg}$ ) and II (treated with $50 \mathrm{mg} / \mathrm{kg}$ ), and reference (treated with the standard glibenclamide). The diabetic free group was designated as normal control. Results obtained revealed that oral administration of aqueous extract of $C$. papaya leaf on alloxan-induced diabetic albino rats significantly reversed the damage associated with alloxan-induced diabetes revealing its hypoglycemic, liver and renal function integrity effects. The presence of phytochemicals and phytonutrients found in C. papaya could explain the observed pharmacological property of the studied extract. This study has revealed the biochemical effects of aqueous extract of C. papaya leaf on alloxan-induced diabetic albino rats.
\end{abstract}

Keywords: Alloaxan, Aqueous extracts, Biochemical effects, Carica papaya

\section{INTRODUCTION}

Different diseases affect the health of living organisms on this planet Earth. Man through his efforts has deployed different therapies [1] to ameliorate, prevent, salvage or cure some of the diseases. Among the therapies, the use of synthesized or compounded drugs; and plants are the two most accepted ones that have been confirmed effective against disease causing microorganisms [1-5]. It has been reported that most of the synthesized drugs are the chemical analogues of compounds derived from plants [69]. Different authors have reported that medicinal plants are those plants that have bioactive constituents with physiological activity against disease causing pathogens [10-14]. These bioactive constituents according to Duru et al. [15]; Edeoga et al. [16]; Okwu [17]; Okwu and Ekeke [18]; and Duru et al. [19], are phytochemicals, vitamins, minerals and proximate contents found in plants. Apart from the phytochemicals, the vitamins, minerals and proximate contents found in plants are classified as phytonutrients [20-22]. Phytochemicals and phytonutrients interact to bring out their known effects against disease causing pathogens that influence the health of other living organisms negatively [23].

Carica papaya is among the known medicinal plants with both phytochemicals and phytonutrients that interact to improve the health of diseased living organisms. $C$. papaya is commonly known as pawpaw and belongs to the family Caricaceae. It is believed to have originated in the tropics of the Americans. Duru et al. [24] noted that $C$. papaya is an important plant containing many medicinally active principles. The usefulness of different parts of $C$. papaya has been reported by different authors. Unripe fruit sap can be used against many infections [25] and crude juice extract has medicinal values [26] like malaria [27]. The antihypertensive property [28]; phytochemicals and nutrients evaluation [29] of C. papaya leaves have been reported. Hasimuna et al. [3o] reported the analgetic activity of papaya (Carica papaya L.) leaves extract. Other compounds such as benzylgucosinolate, phenylpropanoids as well as enzymes in $C$. papaya have also been reported [31-34]. Locally, the Igbos and the Yorubas address $C$. papaya as okpurukwa" and "Ibepe" respectively. Amadi et

Received o7 November 2017; Accepted 31 December 2017

*Corresponding Author

Ezekwe Ahamefula

Department of Medical Biochemistry, Imo State University, Owerri, Nigeria

Email: ezekweahamefulaimsu@gmail.com

(CThis article is open access and licensed under the terms of the Creative Commons Attribution License (http://creativecommons.org/licenses/by/4.o/) which permits unrestricted, use, distribution and reproduction in any medium, or format for any purpose, even commercially provided the work is properly cited. Attribution - You must give appropriate credit, provide a link to the license, and indicate if changes were made. 
al. [35] noted that though the leaves of C. papaya are not among the known conventional vegetables but they are sometimes eaten as prescribed by herbalist to remedy some disease conditions that are prevalent in Nigeria.

Diabetes mellitus is among the prevalent disease conditions in many parts of the world [36-39]. In recent years, progress has been made with use of synthetic drugs in the treatment of diabetes. However, due to limitations of the available medications, there is need to move towards phytomedicine for herbal formulation against the disease diabetes.

The present study looked into this area, and investigated the biochemical effects of aqueous extract of $C$. papaya leaf on alloxan-induced diabetic albino rats.

\section{MATERIALS AND METHODS}

\section{Source and preparation of plant material}

Leaves of C. papaya were collected from Imo State University school farm, Owerri, Nigeria. The collected leaves were identified by Prof. F. N. Mbagwu of Plant Science and Biotechnology Department, Imo State University as C. papaya leaves. The leaves were air dried and powdered.

\section{Preparation of extract}

Two (2) kilograms of the powder sample were soaked in 2.0 $\mathrm{L}$ of distilled water for $48 \mathrm{~h}$ at room temperature. Removal of the solvent from the extract took place under reduced pressure through filtration, followed by evaporation to dryness at $36^{\circ} \mathrm{C}$, to yielded $200 \mathrm{~g}(10 \%)$ of a dark green residue as filtrate.

Experimental animals, alloxan induction, and experimental design

A total of one hundred male albino rats of Wistar strain of the same age, weighing between 180-220 g were purchased from the animal colony of Imo State University school farm, and were transported to the animal colony of Department of Medical Biochemistry of the same citadel of learning. There, the rats were placed in standard cages for $7 \mathrm{~d}$ to acclimatize to their new environment. Pelletized commercial rat feed (Vital feed growers, a subsidiary of Nigeria PLC), and potable water were given to the rats ad libitum within this period. The study was approved by the Animal Welfare and Ethics Committee of Imo State University, Nigeria, with the reference number (IMO/DEC/MEDBCM/O20). All conditions of animal use were adhered to as obtained from National Institute of Health (NIH), Guide for Care and Use of Laboratory Animals [40]. The limit doses test of up and down procedures according to OECD [41] and Dixon [42] were followed for acute oral toxicity studies $\left(\mathrm{LD}_{50}\right)$ and the toxic dose for the extract was found to be well above 1000 $\mathrm{mg} / \mathrm{kg}$. After acclimatization period, the rats were allocated to groups of twenty rats each. Alloxan $150 \mathrm{mg} / \mathrm{ml}$ and diabetes was induced by intraperitoneal administration of aqueous alloxan monohydrate $(150 \mathrm{mg} / \mathrm{kg} \mathrm{b}$. w) to some of the groups. The rats with blood glucose level greater than $200 \mathrm{mg} / \mathrm{dl}$, three days post-induction, were considered diabetic.

The treatments given to the animals are designated as follows

Normal control: No alloxan induced and no aqueous extracts of C. papaya

Diabetic control: Alloxan induced diabetic rats with no aqueous extract of $C$. papaya leaf

Group I: Alloxan induced diabetic rats given aqueous extract of C. papaya leaf ( $200 \mathrm{mg} / \mathrm{kg})$.

Group II: Alloxan induced diabetic rats given aqueous extract of C. papaya leaf (50 $\mathrm{mg} / \mathrm{kg}$ ).

Reference: Alloxan induced diabetic rats treated with glibenclamide (group used as standard).

The treatment of the rats lasted for twenty-one days, and five rats from each group were sacrificed on day zero (day 0 ; three days post-induction), after seven days (day 7), after fourteen days (day 14), and after twenty-one days (day 21).

\section{Blood sample collection}

Five rats from each group were reweighed, anaesthetized with chloroform vapour and dissected during each set of rats`sacrifice. Blood was collected by cardiac puncture into clean tubes for biochemical assays.

\section{Biochemical assay}

Serum aspartate aminotransferase (AST), and alanine aminotransferase (ALT) [43], Alkaline phosphatase (ALP) [44], Creatinine and urea $[45,46]$ were analysed. Levels of sodium, potassium, chloride, bicarbonate, direct and conjugated bilirubin; and blood glucose were estimated spectrophotometrically by using standard ready to use kits from Randox Laboratory Ltd.

\section{Statistical analysis}

Results were presented as means and standard deviations of five determinations. Fig. were used to present the results for better and clear understanding, while the test groups were compared to the diabetic control, normal control and reference group using Anova at $\mathrm{p}<.0 .05$.

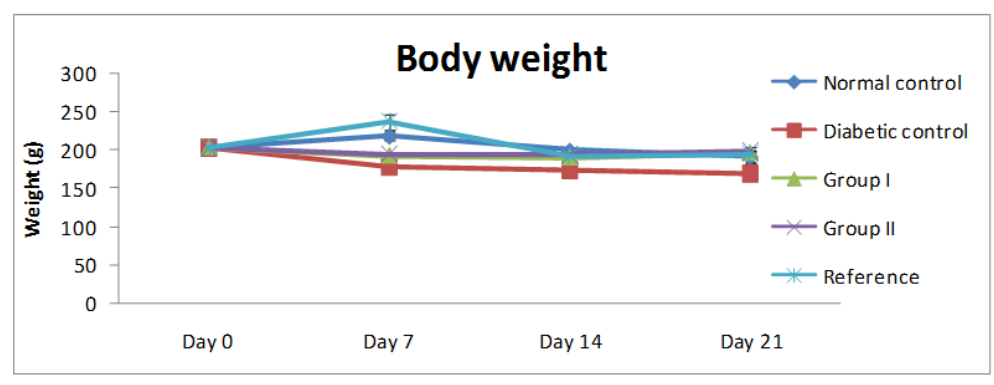

Fig. 1: Weight of rats for the number of days 


\section{RESULTS AND DISCUSSION}

The use of plant to treat disease conditions is as old as mankind on this planet Earth [39, 47]. It has been noted that diabetes is a disease associated with weight reduction [48]. Such observation was clearly seen in diabetic control group as represented in fig. 1. Diabetic control group had progressive reduction in weight (fig. 1), while the weight change observed in groups I and II, compared favorably with those of normal control and reference (fig. 1). C. papaya leaf extracts used in this study may have possessed poor appetite and digestion stimulation properties which influence the efficiency in utilization of feed, resulting in poor growth. This speculation is not in line with the reports of Mahmood et al. [49], and Tanko et al. [50]. The weight reduction observed in diabetic condition has been linked to insufficient insulin, which prevents the body from getting glucose from the blood into the cells to use as energy. Hence, the body reverts to the burning of fats of the body and muscle for energy, which results in the overall weight loss of body weight.

Diabetes is known to bring about the structural and functional changes in intestinal glucose absorption [51]. Glucose increase is paramount in diabetic condition [52]. The glucose level of normal control group was the least and ranged from $71.54 \pm 2.57 \mathrm{mg} / \mathrm{dl}$ on first day (day o) to $69.19 \pm 1.54 \mathrm{mg} / \mathrm{dl}$; those of groups I (202.18 $\pm 1.05-$ $160.75 \pm 1.25 \mathrm{mg} / \mathrm{dl})$ and II (207.17 $\pm 0.89-172 \pm 1.23 \mathrm{mg} / \mathrm{dl})$ progressively decreased after day 7 , and were significant $(\mathrm{p}<0.05)$ when compared to diabetic control group, but compared favorably with those of the reference group (fig. 2). Glucose level of diabetic control group was progressively on the increase with days as against those of groups I and II; and reference (fig. 2). This result may project $C$. papaya leaves as possible anti-hyperglycemic agent. Hence, confirming previous reports on the plant and some species of the family [52]. Several studies have noted that the biological activities of $C$. papaya could be due to the presence of phytochemicals such as flavonoids, alkaloids, steroids and quinones found in the plant [5354]. Interactions between the phytochemicals and phytonutrients earlier reported on $C$. papaya leaves by Agomuo et al. [55], could be behind the ability of the studied leaf extracts to bring about the reduction effect on glucose level of diabetic rats as observed in the present study. The hypoglycemic activity of $C$. papaya leaves in the present study is in line with previous report on the fruit and leaves by Aruoma et al. [56]; and that of Danese et al. [57] on fermented papaya preparation.

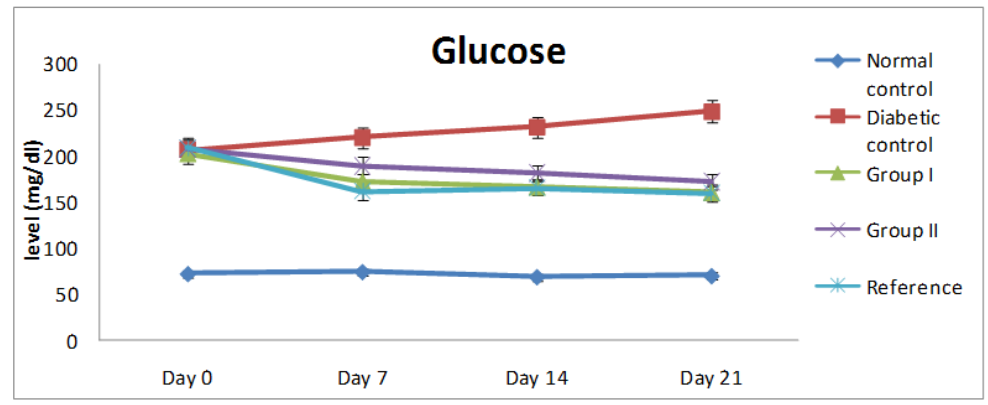

Fig. 2: Glucose levels in rats for the number of days

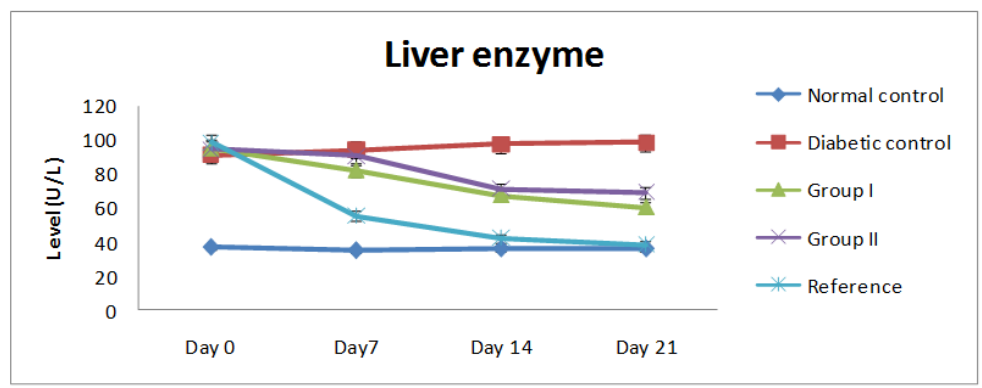

Fig. 3: AST levels in rats for the days

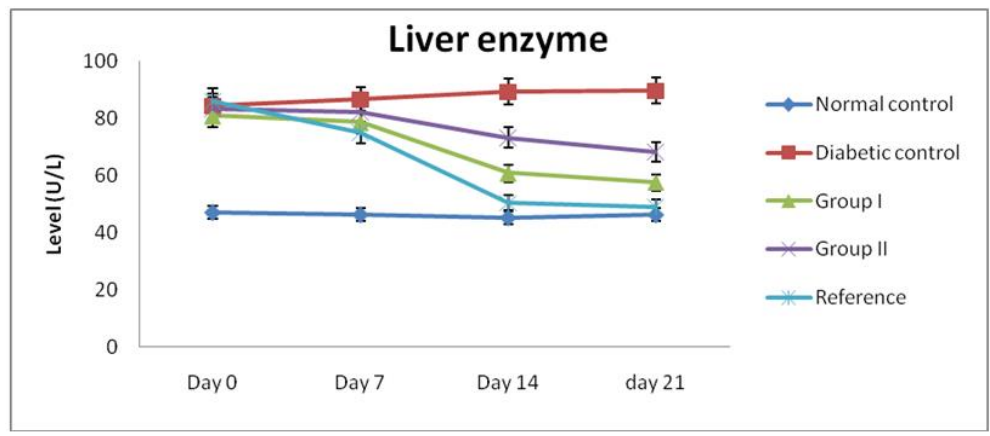

Fig. 4: ALT levels in rats for the days 


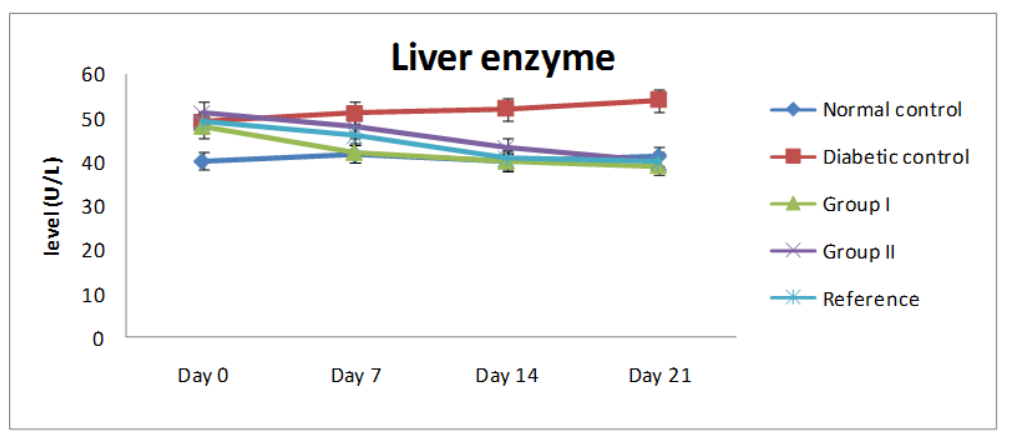

Fig. 5: ALP levels in rats for the days

Liver balances the glucose levels [58] and abnormal liver function may lead to type 2 diabetes [59]. AST and ALT liver enzymes are considered as markers of hepatocellular health [60-65]. The observed levels of AST, an ALT of groups I and II significantly $(\mathrm{p}<0.05)$ reduced against diabetic control group after day 7 , but compares favorably with the reference group (fig. 3 and 4 ). The observation of the present study showed that impairment in the liver function caused by the induction of diabetes with alloxan, could be restored by administration of $C$. papaya leaf extracts. This could be attributed to the bioactive constituents present in the leaf extracts [52]. ALP levels in groups I and II also followed the same order as in AST and ALT levels in the present study (fig. 5).
According to Nwogo et al. [39], levels of renal markers such urea and creatinine are known to increase in diabetic condition. The progressive increase in urea (fig. 6) and creatinine (fig. 7) of diabetic control in the present study is in line with the observation of Nwaogo et al. [39]. A notable elevation in the level of urea during diabetes has been associated with increased catabolism of both the liver and plasma proteins that accompany glyconeogenesis [66]. C. papaya leaf extracts used in this study exhibited potent anti-diabetic activity with the significant reduction of urea and creatinine levels of groups I and II in this study against diabetic control group but compares favourably with the reference group (fig. 6 and 7 respectively).

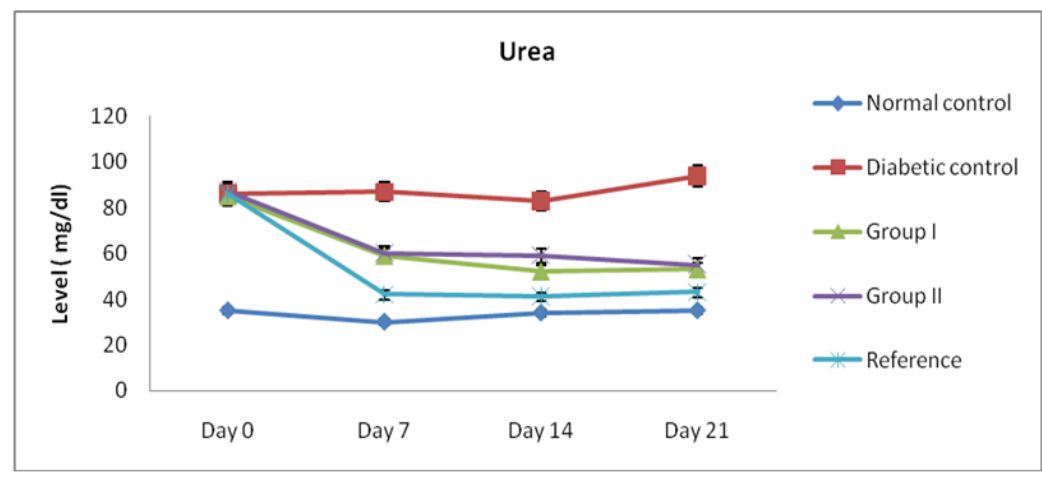

Fig. 6: Urea levels in rats for the days

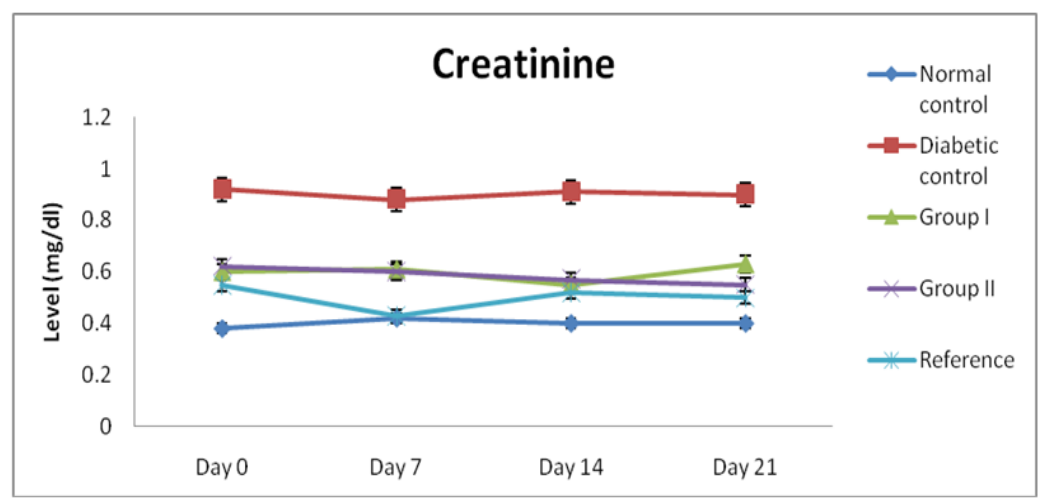

Fig. 7: Creatinine levels in rats for the days 


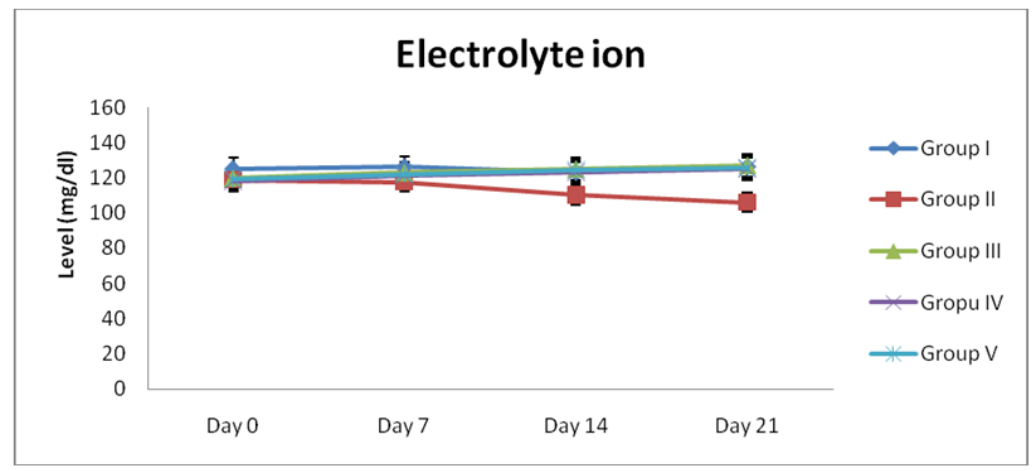

Fig. 8: $\mathrm{Na}^{+}$levels in rats for the days

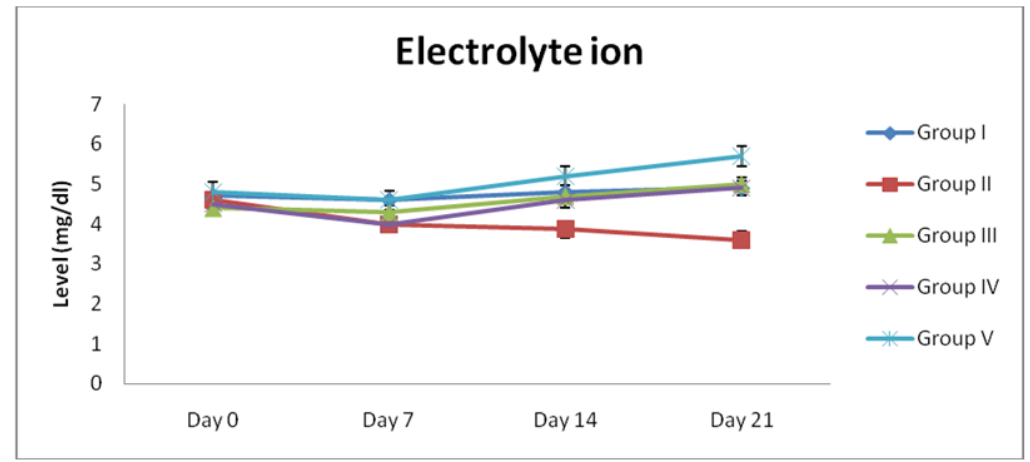

Fig. 9: $\mathrm{K}+$ levels in rats for the days

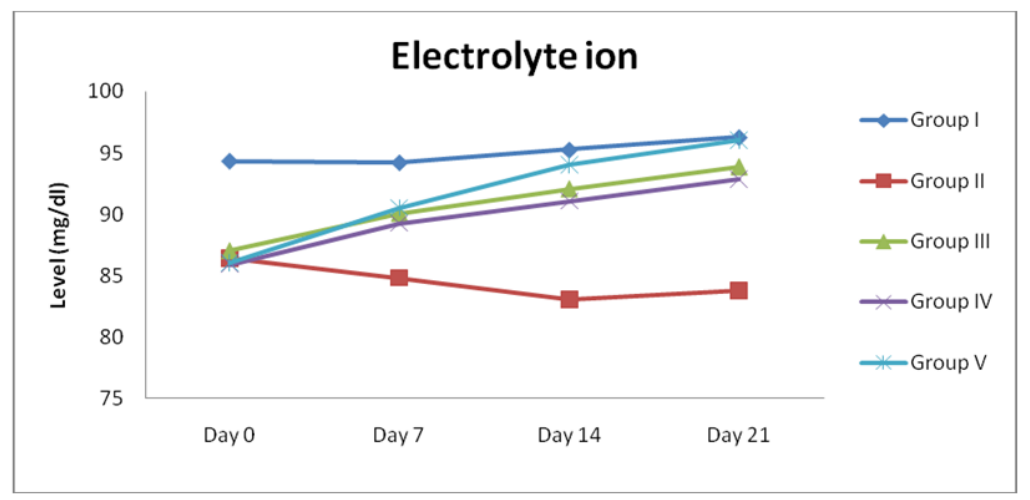

Fig. 10: Cl-levels I rats for the days

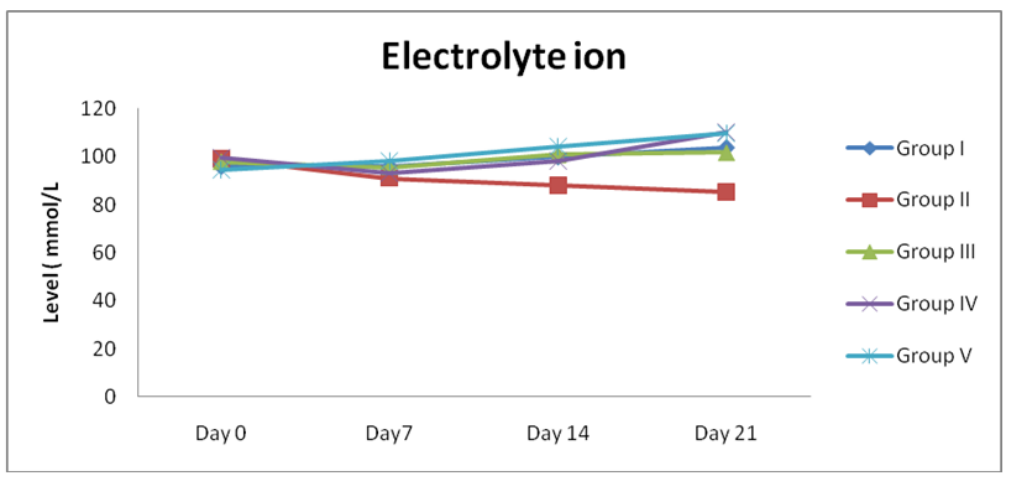

Fig. 11: $\mathrm{HCO}_{3}$-levels I rats for the days 
The kidney regulates fluid and ion balance of the plasma by excretion of urine [67-69]. Though the reabsorption processes depend on mineralocorticoid aldosterone, which is monitored by the kidney; and ion pumps in the body [70]. There was a significant retention of $\mathrm{Na}^{+}, \mathrm{K}^{+}, \mathrm{Cl}^{-}$and $\mathrm{HCO}_{3}$-electrolytes after day 7 , in diabetic control group against those of groups I and II, normal control and reference group. Excretion of electrolyte ions in groups I and II favorably compared to those of normal control and reference group in this study (fig. 8-11). The observed retention of the electrolyte ions in diabetic control rats when compared to those of test groups I and II, normal control and reference is in line with the observations of Khalid et al. [71] and Al-Jameil [72] on hyponatraemia; partially in line with Wang et al. [73], who reported that only $0.6 \%$ of diabetes had hypokalemia and $1.2 \%$ of diabetes subjects had hyperkalemia; and agree with the observation of Al-Jameil [72] and Bayejid et al. [71] on chloride levels in diabetic condition. However, the observed electrolytes in groups I and II, compared favourably with those of normal control and reference group as presented in fig. 8-11 respectively.

\section{CONCLUSION}

Conclusively, the administration of aqueous extract of $C$. papaya leaf on alloxan-induced diabetic albino rats significantly reversed the damage associated with alloxaninduced diabetes revealing its hypoglycemic, liver and renal function integrity. The presence phytochemicals and phytonutrients found in C. papaya could explain the observed pharmacological property of the studied extract. This study has revealed the biochemical effects of aqueous extract of $C$. papaya leaf on alloxan-induced diabetic albino rats.

\section{CONFLICT OF INTERESTS}

The authors declare no conflict of interests over this article. The arrangement of the authors was properly agreed by the all the authors involved.

\section{REFERENCES}

1. Duru M, Nwanekwu K, Ugbogu A, Joseph A, Amadi C, Ujubuonu P. Urine therapy and its effects on some biochemical parameters using rats. Continental J. Biomedical Science. 2013;7: 12-17.

2. World Health Organization. Declaration of Alma Ata: International Conference on Primary Healthcare, Alma Ata.1978, USSR.6-12 September, 1978. www. who. int/hpr/NPH/does/declaration-almaata. pdf

3. Duru M, Amadi C, Ugbogu A, Eze A, Amadi B. Phytochemical, vitamin and proximate composition of Dacryodes edulis fruit at different stages of maturation. Asian Journal of Plant Science and Research. 2012;2: 437-441.

4. Duru M, Amadi B, Agomuo E, Eze A. Chemical Profile of an anti-malarial concoction "Udu" used in Umunchi autonomous community in Isiala Mbano L. G. A of Imo State, Nigeria. Journal of Emerging Trends in Engineering and Applied Sciences. 2012;3 :444-447.

5. Duru M, Nwanekwu. Assessment of urine on body weight, CD4 cells and testosterone hormone. Canadian Journal on Computing in Mathematics, Natural Sciences, Engineering and Medicine. 2013;4, 56-60.

6. Agomuo E, Duru M, Amadi B, Amadi P, Ugwokaegbe, P. Effect of caffeine on some selected biochemical parameters using rat model. Advances in Biology,
Volume 2017, Article ID 9303276, 8 pages. https://doi. org/10.1155/2017/9303276

7. Ugbogu AE, Okezie E, Uche-Ikonne C, Duru M, Atasie OC. (2016). Toxicity evaluation of the aqueous stem extracts of Senna alatain Wistar rats. American Journal of Biomedical Research. 2016;4: 80-86.

8. Schmelzer GH, Gurib-fakin A. Plant resources of tropics African: Medicinal plants I. PROTA foundation, Wageningen, Netherland, 2008;791.

9. Koehn FE, Carter GT. The evolving role of natural products in drug discovery. Nat. Rev. Drug Discov. 2008;4:206-220.

10. Amadi B, Onuoha N, Amadi C, Ugbogu A, Duru M. Elemental, amino acid and phytochemical constituents of fruits of three different species of eggplant. Int. J Med. Aromatic Plants.2013;3: 200203.

11. Amadi B, Duru M, Agomuo E, Amadi P, Onedibe O. Nutritional, phytochemical and sensory evaluation of "mberiagworagwo" traditional food of Uruagunnewi People in Anambra State, Nigeria. Journal of Advances in Biology and Biotechnology. 2017;14:1-8.

12. Nwachukwu MI, Duru MKC, Nwachukwu IO. Antifungal properties and effects of fresh, oven dried uncooked and cooked seeds of Buchholzia coriacea on haematology and kidney. Elixir Food Science. 2013;64:19350-19356.

13. Nwachukwu MI, Duru MKC, Nwachukwu IO, Obasi $\mathrm{CC}$, Uzoechi AU, Ezenwa CM, Anumodu CK. In vitro phytochemical characterization and antibacterial activity of Newbouldia laevis (Boundary tree) on Escherichia coli and Staphylococcus aureus. Asian Journal of Microbiology and Biotechnology.2017;2:30-36.

14. Duru M, Nwadike C, Ozugwu J, Eboagwu I. Bioactive constituents of Pleurotus squarrosulus(Mont.) Singer and effect of Its dietary incorporation on body/organ weights and lipid profile levels of rats placed on high cholesterol diet. Academic Journal of Chemistry.2017;, 28-37.

15. Duru M, Nwadike C, Ezekwe A, Nwaogwugwu C, Eboagwu I, Odika P, Njoku S, Chukwudoruo C. Evaluation of nutritional, anti-nutritional and some biochemical studies on Pleurotus squarrosulus (Mont.) singer using rats. African Journal of Biochemistry Research. 2018;12 :7-27.

16. Edeoga HO, Okwu DE, Mbaebie BO. Phytochemical constituents of some Nigerian medicinal plants. Afr. J. Biotechnol. 2005;4:685-688.

17. Okwu DE. Phytochemicals, vitamins and mineral contents of two Nigerian medicinal plants. Int. J. Mol. Adv. Sci.2005;1:375-381.

18. Okwu DE, Ekeke O. Phytochemical screening and mineral composition of chewing sticks in South Eastern Nigeria. Global $J$ Pure and Applied Sci.2003;9:235-238

19. Duru M, Ugbogu A, Amadi B. Effect of Solanum macrocarpon fruit on haematoloy, hepatic and renal function. Advances in Biochemistry.2013;1: 28-32.

20. Amadi BA, Arukwe U, Duru MKC, Amadi CT, Adindu EA, Egejuru L, Odika PC. Phytonutrients and antinutrients screening of $D$. edulis fruits at different maturation stages. J. Nat. Prod. Plant Resour. 2012;2:530-533.

21. Amadi BA, Duru MKC, Agomuo E. N. Chemical profiles of leaf, stem, root and flower of Ageratum conyzoides. Asian Journal of Plant Science and Research.2012;2 :428-432. 
22. Duru M, Ugbogu A, Amadi B, Odika P, Chima-Ezika O, Anudike J, Osuocha K. Chemical constituents of Buchholzia coriacea seed. Proceedings of the 35th Annual International Conference, Workshop and Exhibition of Chemical Society of Nigeria.2012;2:39-45.

23. Duru M, Amadi B, Ugbogu A, Eze A. Effects of "udu", an antimalarial herbal preparation on visceral organ weight and blood lipid profiles in wistar rats. JPCS.2014;8:1-7.

24. Duru MKC, Amadi BA, Amadi CT, Lele KC, Anudike JC, Chima-Ezika OR, Osuocha K. Toxic effect of Carica papaya bark on body weight, haematology, and some biochemical parameters Biokemistri. 2012;24:67-71.

25. Okigbo RN, Mmeka EC. An appraisal of phytomedicine in Africa. KMITL Sci. Tech J.2006;6:83-94.

26. Iweala EE, Uhegbu FO, Odu GN. Preliminary in vitro antisickling properties of crude juice extract of Persea americana, Citrus sinensis, Carica papaya and ciklavit. Afri. J. Trad. CAM. 2012;7:113-117.

27. Mantok C. Multiple usage of green papaya in healing at Tao garden. Tao garden healing spa and Resort. Thailand. www. tao-garden. com.2005.

28. Asaolu MF, Asaolu SS, Adanlawo IG, Aluko BT, Allismith YR, Ibitoye Y, Abiodakun A M. Comparative chemical composition of leaves of some selected antihypertensive medicinal plants in Nigeria. Der Pharma Chemica.2010;2:11-15.

29. Ayoola PE, Adeyeye A. Phytochemical and nutrient evaluation of Carica papaya (Pawpaw) leaves. IJRRAS.2010;5:325-328.

30. Hasimuna P, Suwendara Ernasaria GI. Analgetic activity of papaya (Carica papaya L.) leaves extract. Procedia Chemistry.2014;13:147-149.

31. Brocklehurst K, Salih E. Fresh non-fruit latex of Carica papaya contains papain, multiple forms of Chymopapain A and papaya proteinase omega. Biochemical Journal.1985;228:525-529.

32. Franco MRB, Amaya DR, Damasco MH, Carrilo JLL. Volatile compounds and flovor of pawpaw (Carica papaya) a reappraisal. AlimentoeNuvilao.1993;5:99108.

33. Bennet RN, Kiddle G, Walls G. Biosynthesis of Nylglucosinolate, Cyanogen glucosides and phenyl propanoids. Caricap papaya. Phytochemistry.1997;45:59-66.

34. Flath RA, Forrey RR. Volatile components of papaya (Carica papaya L. sole variety). J. Agr. Food Chem.1977;25:103-109.

35. Amadi BA, Agomuo EN, Duru MKC. Toxicological studies of Asmina triloba leaves on haematology, liver, kidney using rat model. International Science Research Journal.2013;4:11-17.

36. Balkau B, Charles MA, Eschwege E. Epidemiological discourse on new criteria on diabetes. Mol. Endocrinol.2000;2:229-234.

37. Maiti R, Jana D, Das UK, Ghosh D. Antidiabelic effect of aqueous extract of seed of Tamarindus indica in streptozotocin induced diabetic rats. J. Ethnopharmacol.2004;92:85-91.

38. Murray M. Encylopedia of natural medicine. $2^{\text {nd }}$ Edn., Prima Health Publishing, Rocking, USA, 2000;pp.401.

39. Nwogo AO, Kalu MK, Uchechukwu O, Glory O. Hypohlycemic effects of aqueous and methanolic leaf extract of Vitex doniana on Alloxan induced diabetic albino rats. Journal of Medical Sciences.2013;13:700707.
40. NIH. National Research Council Guide for the Care and Use of Laboratory Animals, Publication no. 85123(rev.), National Institute Health, Bethesda, Md, USA. 1985

41. OECD. Guidelines for testing chemical, acute oral toxicities up and down produce. OECD Reports 425.2001;pp.1-26.

42. Dixon WJ. The up and down method. Neutrosci. Biohehav. Rev.1991;15:47-50.

43. Reitman S, Frankel S. Colorimetric GOT and GPT determination. Am. J. Clin. Pathol.1957;28, 58-63.

44. Babson LA, Greenley SJ, Coleman CM, Philips GD. Serum alkaline phosphatase determination. Clin. Chem.1966;12:482-490.

45. Larsen K. Creatinine assay by a reaction-kinetic principle. Clin. Chim. Acta.197;41:209-21

46. Searcy RL, Reardon JE, Foreman JA. Enzymatic GOP and GPT determination. Am. J. Med. Technol.1967;33:15-20.

47. Duru M, Amadi B, Ugbogu A, Onuoha, N. Effect of "nduduagworagwo" traditional food on haematology, hepatic and renal function of rats. Asian Journal of Agriculture and Food Science.2013;1:21-26.

48. Yassin MM, Ashour ARA, Eiyazi NR. (2004). Alteration in body weight, protein profile, non-protein nitrogen constituents and kidney structurein diabetic rats under glibenclamide tratement. Islamic Univ. Gaza.2004;12:37-54.

49. Mahmood SA,Talat A, Karim S, Khursthid R, Zia A. Effect of cinnamon extract on blood glucose level and lipid profile in alloxan induced diabetic rats. Pak. J. Physiol.2011;7:13-16.

50. Tanko Y, Sada NH, Mohammed KA, Jimoh M, Mohammed A. Effect of ethanolic extract of Caralluma daizellii on serum electrolytes levels on fructose-induced diabetes in Wistar rats. Ann. Biol. Res.2013;4:157-161.

51. Hamden K, Keskes H, Belhaj S, Mnafgui K, Allouche, N. Inhibitory potential of omega-3 fatty and fenugreek essential oil on key enzymes of carbohydrate-digestion and hypertension in diabetes rats. Lipids Health Dis.2011;10. 10.1186/1476-511X-10-226

52. Juárez-Rojopa IE, Tovilla-Zárateb CA, AguilarDomíngueza D E, Roa-de la Fuentec LF, LobatoGarcíac CE, Blé-Castilloa JL, López-Merazd L, Juan C, Díaz-Zagoyae JC, Bermúdez-Ocañab DY. Phytochemical screening and hypoglycemic activity of Carica papaya leaf in streptozotocin-induced diabetic rats. Rev Bras Farmacogn.2014;24:341-347.

53. Sanders RA, Rauscher FM, Watkins JB. Effects of quercetin on antioxidant defense in streptozotocininduced diabetic rats. J. Biochem. Mol. Toxicol.2001;15:143-149.

54. Ghosh D, Konishi T. Anthocyanins and anthocyaninrich extracts: role in diabetes and eye function. Asia Pac. J. Clin. Nutr. 2007;16:200-208.

55. Agomuo EN, Duru MKC, Amadi BA. Some bioactive constituents of Asmina triloba (pawpaw) leaf variety. International Science Research Journal.2013;4:18-22.

56. Aruoma OI, Hayashi Y, Marotta F, Mantello P, Rachmilewitz E, Montagnier L. Applications and bioefficacy of the functional food supplement fermented papaya preparation. Toxicology.2010;278, 6-16.

57. Danese C, Esposito D, D’Alfonso V, Cirene M, Ambrosino M, Colotto M. Plasma glucose level decreases as collateral effect of fermented papaya preparation use. Clin. Ter. 2006;157:195-198. 
58. Murray RK, Granner DK, Mayers PA, Rodwell VW. Harper's Biochemistry, $25^{\text {th }}$ edition, Appleton and Lange, Philadelphia. 2000;pp.179-203, 621-630.

59. Marchesini G, Brazil M, Bianchi G, Tomassetti S, Bugianesi E, Lenz M, McCullough AJ, Natale S, Forlani G, Melchionda N. Nonalcoholic fatty liver disease a feature of the metabolic syndrome. Diabetes.2001;50:1844-1850.

6o. Friday EU. Clinical uses of enzymes, In: Conceptual Enzymology, (Innolex Printers and Publishers, Calabar.2004;pp. 190-212

61. Nwachukwu MI, Duru MKC, Amadi BA, Nwachukwu IO. Comparative evaluation of phytoconstituents, antibacterial activities and proximate contents of fresh, oven dried uncooked and cooked Samples of Buchholzia coriacea Seed and their effects on hepatocellular Integrity. International Journal of Pharmaceutical Science Invention.2014;3 :41-49.

62. Wurochekke AU, Anthony AE, Obidah W. Biochemical effects on Liver and kidney of rats administered aqueous stem bark extract of Xemenia americana. African Journal of Biotechnology.2008;7:2777-2780.

63. Duru M, Amadi B, Eze A, Ugbogu, A. Effect of "mgbam" traditional food on haematological profile and some selected biochemical parameters following consumption. Elixir Food Science.2003;64:19345-19349.

64. Duru MK, Amadi BA, Amadi CT, Ugbogu AE, Onuoha, NL. Assessment of "nduduagworagwo" a traditional recipe of Akokwa people in Ideato North L. G. A of Imo State, Nigeria on body weight and some biochemical parameters. Continental J. Food Science and Technology.2013;7:15-21.

65. Duru MKC, Amadi BA, Eze AE, Ugbogu AE, Onuoha N. In vivo studies of Solanium aethiopicum fruit on some biochemical parameters using rats. Journal of Chemical and Pharmaceutical Research.2013;5:1-4.
66. Khusk I, Dahot MU, Baloach SA, Bhutto MA. The evaluation of soybean extracts in alloxan-induced rabbits. World Applied Sci. J.2010;8:22-25.

67. Duru, MKC, Adindu EA, Odika, PC, Amadi B, Okazi ER. Consequence of long-term consumption of water from Nworie River (Owerri, Nigeria) on haematological, hepatic, and renal functions using rat model. Biokemistri.2012;24:52-57.

68. Robert KM, Daryl KG, Peter AM, Victor WR. Harper`s illustrated Biochemistry 26th edition. McGraw Hill, New York.2003

69. Akubugwo EI, Duru MKC. Biochemical implications of the consumption of water from Otamiri River, Owerri, Imo State, Nigeria. Journal of Emerging Trends in Engineering and Applied Sciences (JETEAS), 2011;2 : 934-937.

70. Harper HA, Rodwell VM, Maryers PA. Review of physiological chemistry, 16th edition, Large medical Publishers. Los Altos, California.1975.

71. Bayejid H, Ashikur RB, Shamimul H, Mahmudul H, Mesbah U. Estimation of serum electrolytes in non Insulin dependent (type 2) diabetic patients in Bangladesh. Scientific Research Journal(SCIRJ).2014;II (XII):23-39.

72. Khalid R, Khalid S, Khaled AR, Roderick H, Abdul M, Khalid A. Correlation between serum electrolytes and fasting glucose and Hb1Ac in Saudi diabetic patients. Biol. Trace. Elem. Res. 2011;144:463-8.

73. Al-Jameil N. Estimation of serum electrolytes in diabetes patients of Saudi region. Life. Sci. J. 2014;11:378-380.

74. Wang S, Xuhong H, Yu L, Huihuan L, Li W, Yaquian B, Weiping J. Serum electrolytes relation to macrovascular complications in Chinese patients with diabetes mellitus. Cardiovas. Diabet. 2013;12:146-55. 